\title{
PENGARUH MODAL KERJA, PERILAKU KEWIRAUSAHAAN DAN KETERAMPILAN ADMINISTRASI TERHADAP PERKEMBANGAN USAHA PARA PEDAGANG DI PASAR BARU KOTA KUNINGAN
}

\author{
${ }^{1)}$ Pupu Saeful Rahmat, ${ }^{2)}$ Iskandar \\ ${ }^{1)}$ Sekolah Pascasarjana Universitas Kuningan \\ J1. Pramuka No.67, Purwawinangun, Kec. Kuningan, Kabupaten Kuningan, Jawa Barat 45512 \\ Email: poesya59@gmail.com \\ ${ }^{2)}$ Sekolah Pascasarjana-Universitas Kuningan \\ J1. Pramuka No.67, Purwawinangun, Kec. Kuningan, Kabupaten Kuningan, Jawa Barat 45512 \\ Email: ishasan8562@gmail.com
}

\begin{abstract}
The problem in this research is lack of business development of actors informal sector in Pasar Baru - Kuningan District. The purpose of this study is as follows: (1) to determine the effect of simultaneously working capital, entrepreneurial behavior and skills to manage the administration of the development of the informal sector in Pasar Baru Kuningan; (2) to determine the effect of working capital to the development of the informal sector in Pasar Baru Kuningan; (3) to determine the effect of entrepreneurial behavior to the of the informal sector in Pasar Baru Kuningan; (5) to determine the effect on the development of skills to manage the administration of informal sector businesses in Pasar Baru - Kuningan. The method used in this research is quantitative method type survey. The hypothesis of this study are Working capital, entrepreneurial behavior and skills to manage the administration of influence simultaneously to the development of informal sector enterprises. Research results are: working capital, entrepreneurial behavior and skills to manage the administration jointly influence simultaneously to the development of informal sector businesses in Pasar Baru-Kuningan. Working capital has a positive and significant impact on the development of informal sector businesses in Pasar Baru-Kuningan. This means that the presence of additional working capital will also increase business development in the informal sector of Pasar Baru - Kuningan District.
\end{abstract}

Keywords: Working Capital, Entrepreneurial Behavior, Growth Effort, Skills in Managing the Administration.

\begin{abstract}
ABSTRAK
Tujuan penelitian ini adalah sebagai berikut: (1) untuk mengetahui pengaruh modal kerja secara simultan, perilaku dan keterampilan kewirausahaan untuk mengelola administrasi pengembangan sektor informal di Pasar Baru Kuningan; (2) untuk mengetahui pengaruh modal kerja terhadap perkembangan sektor informal di Pasar Baru Kuningan; (3) untuk mengetahui pengaruh perilaku kewirausahaan terhadap sektor informal di Pasar Baru Kuningan; (4) untuk mengetahui pengaruhnya terhadap pengembangan keterampilan untuk mengelola administrasi usaha sektor informal di Pasar Baru - Kuningan. Metode yang digunakan dalam penelitian ini adalah metode kuantitatif jenis survei. Hipotesis penelitian ini adalah modal kerja, perilaku kewirausahaan dan keterampilan untuk mengelola administrasi pengaruh secara bersamaan untuk pengembangan usaha sektor informal, Hasil penelitian adalah: modal kerja, perilaku kewirausahaan dan keterampilan untuk mengelola administrasi bersama-sama mempengaruhi secara bersamaan untuk pengembangan usaha sektor informal di Pasar Baru-Kuningan. Modal kerja memiliki dampak positif dan signifikan terhadap perkembangan usaha sektor informal di Pasar Baru-Kuningan. Ini berarti bahwa kehadiran modal kerja tambahan juga akan meningkatkan pengembangan bisnis di sektor informal Pasar Baru - Kabupaten Kuningan.
\end{abstract}

Kata kunci: Modal Kerja, Perilaku Kewirausahaan, Upaya Pertumbuhan, Keterampilan dalam Mengelola. 


\section{PENDAHULUAN}

Kenaikan harga daging ayam dan telor ayam menjadi problema bagi para konsumen dan para pedagang karena kenaikan harga daging ayam dan telor ayam tersebut dikuti dengan kenaikan harga bahan pokok lainnya. Bagi para pedagang, kenaikan harga barang-barang di satu sisi akan berdampak pada perolehan keuntungan yang lebih karena adanya kenaikan harga, tapi di sisi lain juga harus menyiapkan kembali modal berdagang yang cukup besar karena dikhawatirkan adanya kenaikan harga karena adanya kenaikan BBM di sektor informal ini.

Sektor informal mampu menyerap tenaga kerja dengan jumlah yang cukup tinggi apabila dibandingkan dengan sektor formal. Sektor informal menunjukkan adanya peningkatan penyerapan tenaga kerja dari tahun ke tahun, Dalam segi investasi, sektor formal mendapat investasi lebih besar bila dibandingkan dengan sektor informal. Hal tersebut dianggap normal karena banyak orang yang belum berani untuk berinvestasi di sektor informal dikarenakan dalam berinvestasi di sektor informal masih rawan dengan penipuan dan hanya berdasarkan pada kepercayaan, apabila mereka memilih sektor informal maka orang-orang tersebut memilih menjadi wirausaha atau mempunyai usaha sendiri karena dengan mempunyai usaha sendiri menjadi bisa diawasi dengan lebih baik, hal itu yang menyebabkan banyaknya tenaga kerja di sektor informal dari pada di sektor formal.

Penelitian dilakukan di Pasar Baru Kuningan. Adapun rumusan masalah dalam penelitian ini adalah:

1. Bagaimanakah variabel modal kerja, perilaku kewirausahaan, keterampilan mengelola administrasi dan perkembangan usaha sektor informal di Pasar Baru Kuningan?

2. Bagaimana pengaruh simultan modal kerja, perilaku kewirausahaan dan keterampilan mengelola administrasi terhadap perkembangan usaha sektor informal di Pasar Baru Kuningan?

3. Bagaimana pengaruh modal kerja terhadap perkembangan usaha sektor informal di Pasar Baru Kuningan?

4. Bagaimana pengaruh perilaku kewirausahaan terhadap perkembangan usaha sektor informal di Pasar Baru Kuningan?

5. Bagaimana pengaruh keterampilan mengelola administrasi terhadap perkembangan usaha sektor informal di Pasar Baru Kuningan?

Berdasarkan rumusan masalah tersebut, tujuan yang ingin dicapai melalui penelitian ini adalah:

1. Untuk mengetahui gambaran umum variabel modal kerja, perilaku kewirausahaan, keterampilan mengelola administrasi dan perkembangan usaha sektor informal di Pasar Baru Kuningan.

2. Untuk mengetahui pengaruh simultan modal kerja, pendidikan, perilaku kewirausahaan dan keterampilan mengelola administrasi terhadap perkembangan usaha sektor informal di Pasar Baru Kuningan.

3. Untuk mengetahui pengaruh modal kerja terhadap perkembangan usaha sektor informal di Pasar Baru Kuningan.

4. Untuk mengetahui pengaruh perilaku kewirausahaan terhadap perkembangan usaha sektor informal di Pasar Baru Kuningan.

5. Untuk mengetahui pengaruh keterampilan mengelola administrasi terhadap perkembangan usaha sektor informal di Pasar Baru Kuningan.

\section{TINJAUAN PUSTAKA}

\subsection{Perkembangan Usaha Sektor}

\section{Informal}

Perekonomian di Negara Sedang Berkembang dan Negara Maju banyak didorong oleh sektor formal dan sektor 
informal. Sektor informal tumbuh karena adanya tingkat urbanisasi yang cukup tinggi dan sektor formal tidak mampu menyerap tenaga kerja sehingga mereka menciptakan "pekerjaan sendiri".

Menurut Manning (1996:45) bahwa: Keberadaan sektor informal secara "formal" telah diakui sejak awal tahun 1970-an setelah beberapa observasi dilaksanakan di negara-negara berkembang, dan diketemukan bahwa tambahan tenaga kerja yang begitu banyak mengalir ke daerah perkotaan ternyata tidak muncul dalam statistik ketenagakerjaan. Sebagian dari para pendatang baru ini tampaknya menciptakan pekerjaan sendiri atau bekerja pada perusahaan-perusahaan kecil yang dimiliki keluarga.

Kewirausahaan (entrepreneurship) merupakan aktivitas yang sangat penting di era globalisasi ini. Kewirausahaan adalah kemampuan kreatif dan inovatif yang dijadikan dasar, kiat dan sumber daya untuk mencari peluang menuju sukses. Inti dari kewirausahaan menurut Drucker (1959) dalam Suryana (2006:14),

adalah kemampuan untuk menciptakan sesuatu yang baru dan berbeda melalui pemikiran kreatif dan tindakan inovatif demi terciptanya peluang. Istilah kewirausahaan berasal dari terjemahan entrepreneurship, yang dapat diartikan sebagai "the backbone of economy", yaitu syaraf pusat perekonomian atau sebagai "tailbone of economy", yaitu pengendali perekonomian suatu bangsa.

Jadi kewirausahaan merupakan suatu kemampuan dalam menciptakan nilai tambahan di pasar melalui proses pengelolaan sumber daya dengan cara-cara baru dan berbeda, seperti:

1. Pengembangan teknologi,

2. Penemuan pengetahuan ilmiah,

3. Perbaikan produk barang dan jasa yang ada,

4. Menemukan cara-cara baru untuk mendapatkan produk yang lebih banyak dengan sumber daya yang lebih efisien.

Sektor informal dicirikan oleh sejumlah besar produksi berskala kecil dan aktivitas jasa-jasa yang dimiliki oleh perorangan atau keluarga dan dengan menggunakan teknologi yang sederhana. Umumnya para pekerja yang bekerja sendiri di sektor ini hanya sedikit memiliki pendidikan formal, tanpa keterampilan dan kekurangan modal.

Samuelson (1992) mengemukakan bahwa Perkembangan dalam suatu usaha sangat berkaitan erat dengan pendapatan yang diperolehnya, pendapatan itu ialah total uang yang diterima atau terkumpul dalam satu periode. Pendapatan yang diterima oleh pengusaha bukan sebagai harga dari pengusaha melainkan sebagai sebab akibat dari pembentukan harga di berbagai pasar.

Adapun sikap dan perilaku yang harus dijalankan oleh pengusaha dan seluruh karyawan, sesuai yang dinyatakan Kasmir (2008:31) adalah sebagai berikut:

1. Jujur dalam bertindak dan bersikap;

2. Rajin, tepat waktu dan tidak pemalas;

3. Selalu murah senyum;

4. Lemah lembut dan ramah-tamah;

5. Sopan santun dan hormat;

6. Selalu ceria dan pandai bergaul;

7. Fleksibel dan memiliki rasa tanggung jawab;

8. Serius dan suka menolong pelanggan;

9. Rasa memiliki perusahaan yang tinggi.

Kesembilan perilaku tersebut harus dimiliki oleh pengusaha dan karyawan jika mereka ingin melangsungkan aktivitasnya dalam berbisnis dan sukses.

Pada bagian lain, Mc.Clelland dalam Suryana (2006:51), mengemukakan enam ciri perilaku kewirausahaan, yaitu:

1. Keterampilan mengambil keputusan dan risiko yang moderat, serta bukan atas dasar kebetulan belaka.

2. Energik, khususnya dalam berbagai bentuk kegiatan inovatif. 
3. Memiliki sikap tanggung jawab individual.

4. Mengetahui hasil-hasil dari berbagai keputusan yang diambilnya, dengan tolak ukur satuan uang sebagai indikator keberhasilan.

5. Mampu mengantisipasi berbagai kemungkinan di masa mendatang.

6. Memiliki kemampuan berorganisasi, meliputi kemampuan kepemimpinan dan manajerial.

Seorang pengusaha atau pedagang pasti ingin melihat bagaimana perkembangan dari usaha yang telah dirintisnya selama ini. Apakah dari mulai awal dia merintis usaha hingga kini sudah untung atau merugi atau masih berusaha untuk mengembalikan modal yang dikeluarkan untuk membuat usaha. Maka dari itu biasanya para pengusaha atau pedagang melihatnya dari perkembangan usahanya. Perkembangan usaha tidak hanya dilihat dari berapa keuntungan yang sudah dia dapat, tetapi dilihat dari berbagai hal. Samuelson (1992) mengemukakan bahwa:

Perkembangan dalam suatu usaha sangat berkaitan erat dengan pendapatan yang diperolehnya, pendapatan itu ialah total uang yang diterima atau terkumpul dalam satu periode. Pendapatan yang diterima oleh pengusaha bukan sebagai harga dari pengusaha melainkan sebagai sebab akibat dari pembentukan harga di berbagai pasar.

Menurut Abdullah NS (1987) dalam Liya (2007), "Perkembangan usaha adalah suatu ukuran tentang pencapaian usaha yang dilihat dari perkembangan volume usaha, jumlah aset yang dimiliki, dan besarnya laba yang dihasilkan."

Jadi pelaku wirausaha yang mempunyai ciri tersebut dapat membantu dalam perkembangan usaha.

\subsection{Penelitian Terdahulu}

Penelitian Purwanti (2012) tentang Pengaruh Karakteristik Wirausaha, Modal
Usaha, Strategi Pemasaran Terhadap Perkembanga Usaha UMKM di Desa Dayaan dan Kalilondo Salatiga, pekembangan usaha diukur dengan indikator karakteristik wira usaha, kemudahan dan besar modal dan strategi pemasaran. Dalam penelitian ini, terdapat satu indikator yang sama yaitu modal.

Selanjutnya penelitian Insanuddin Lingga dalam penelitiannya (2010) menyatakan bahwa, apabila lama pendidikan meningkat satu tingkat maka pendapatan juga akan meningkat $\mathrm{Rp} 88$ ribu. Berarti hal ini sesuai dengan hipotesis yang menyatakan bahwa terdapat pengaruh positif tingkat pendidikan untuk meningkatkan pendapatan. Berdasarkan hasil nilai elastisitas tingkat pendidikan menunjukkan nilai inelastis artinya persentase peningkatan terhadap tingkat pendidikan akan menghasilkan persentase penambahan terhadap pendapatan yang lebih kecil.

Pendapatan merupakan salah satu ukuran untuk melihat perkembangan usaha. Jadi dalam penelitian ini dapat disimpulkan bahwa semakin tinggi pendidikan seorang pedagang atau pelaku sektor informal maka semakin tinggi pula kemampuannya dalam mengelola usahanya sehingga akan meningkatkan perkembangan usahanya.

Menurut David Mc.Clelland dalam Suryana (2006:51), mengemukakan enam ciri perilaku kewirausahaan, yaitu:

1. Keterampilan mengambil keputusan dan risiko yang moderat, serta bukan atas dasar kebetulan belaka.

2. Energik, khususnya dalam berbagai bentuk kegiatan inovatif.

3. Memiliki sikap tanggung jawab individual.

4. Mengetahui hasil-hasil dari berbagai keputusan yang diambilnya, dengan tolak ukur satuan uang sebagai indikator keberhasilan.

5. Mampu mengantisipasi berbagai kemungkinan di masa mendatang. 
6. Memiliki kemampuan berorganisasi, meliputi kemampuan kepemimpinan dan manajerial.

Jadi pelaku wirausaha yang mempunyai ciri tersebut dapat membantu dalam perkembangan usaha.

\subsection{Kerangka Berpikir}

Untuk meningkatkan pendapatannya ada beberapa faktor yang mempengaruhi perkembangan usaha pada sektor informal diantaranya:

1. Modal Kerja

2. Perilaku Kewirausahaan

3. Keterampilan mengelola administrasi

4. Keterampilan mengelola administrasi

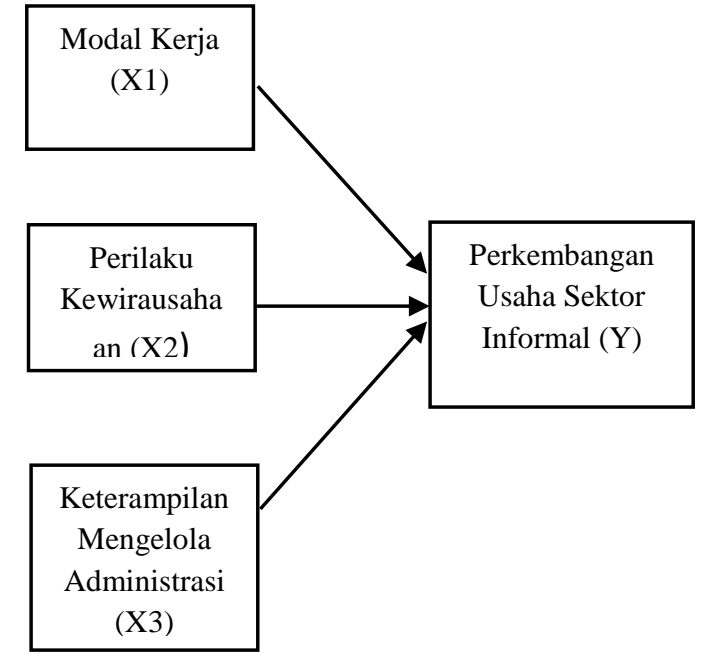

\section{Gambar 1. Kerangka Berpikir}

Perkembangan usaha itu dapat dilihat dari perkembangan naik turunnya laba yang didapat oleh para pedagang. Kemudian mengenai faktor-faktor yang mempengaruhi perkembangan usaha dapat dilihat dari banyaknya modal kerja yang dimiliki baik itu modal sendiri ataupun modal pinjaman, pendidikan formal terakhir yang ditempuh, perilaku kewirausahaan, dan keterampilan dalam mengelola administrasi yang dimiliki oleh pedagang tersebut. Ada beberapa faktor tersebut dapat mempengaruhi perkembangan usaha dari pedagang.

\subsection{Hipotesis}

Berdasarkan kerangka pemikiran di atas, maka dapat dirumuskan hipotesis sebagai berikut:

1. Modal kerja, perilaku kewirausahaan dan keterampilan mengelola administrasi berpengaruh secara simultan terhadap perkembangan usaha sektor informal.

2. Modal kerja berpengaruh terhadap perkembangan usaha sektor informal.

3. Perilaku kewirausahaan berpengaruh terhadap perkembangan usaha sektor informal.

4. Keterampilan mengelola administrasi berpengaruh terhadap perkembangan usaha sektor informal.

\section{METODE PENELITIAN}

Jenis penelitian yang digunakan adalah jenis penelitian kuantitatif dengan metode survey. Populasi dari penelitian ini adalah 330 orang/pedagang terdiri atas pedagang beras, pedagang hasil pertanian, pedagang sayuran, pedagangan hasil peternakan dan perikanan dan pedagang keperluan rumah tangga lainnya. Menentukan ukuran sampel menggunakan teknik pengambilan sampel secara proporsional random sampling memakai rumusan alokasi proportional seperti dalam Riduwan (2010:250) sebagai berikut:

$$
n_{i}=\frac{N_{i}}{N} \cdot n
$$

Jadi, jumlah sampel sebesar 228 orang/pedagang.

Teknik pengumpulan data yang dipakai dalam penelitian ini adalah dengan :

1. Observasi, yaitu dengan melakukan pengamatan secara langsung ke objek penelitian untuk melihat secara langsung kegiatan yang dilakukan.

2. Angket, yaitu daftar pertanyaan yang diberikan kepada orang lain bersedia memberikan respons (responden) sesuai dengan permintaan peneliti. Pemberian angket ini berisi tentang 
pendapatan dan modal kerja dengan skala interval dan tentang pendidikan dengan skala ordinal, kemudian perilaku kewirausahaan dan keterampilan mengelola administrasi dengan skala likert.

Variabel dalam penelitian ini ada 4 (empat) yaitu: 3 (tiga) variabel bebas (independen) dan 1 (satu) variabel terikat (dependen). Variabel bebas antara lain: (1) modal kerja (X1); (2) perilaku kewirausahaan (X2); (3) keterampilan mengelola administrasi (X3). Adapun variabel terikat (dependen) yaitu perkembangan usaha sektor informal.

Teknik analisis data menggunakan analisis regresi linier berganda (multiple linear regression method). Tujuannya untuk mengetahui variabel-variabel yang dapat mempengaruhi pendapatan. Model analisis yang digunakan untuk melihat pengaruh antara variabel-variabel bebas terhadap variabel terikat serta untuk menguji kebenaran dari hipotesis akan digunakan model persamaan regresi berganda sebagai berikut:

$$
\mathbf{Y}=\mathbf{a}_{0}+\boldsymbol{\beta}_{1} \mathbf{X}_{1}+\boldsymbol{\beta}_{2} \mathbf{X}_{2}+\boldsymbol{\beta}_{3} \mathbf{X}_{3}+\boldsymbol{\beta}_{4} \mathbf{X}_{4}+\mathrm{e}
$$

\section{HASIL DAN PEMBAHASAN}

Berdasarkan hasil penelitian, diketahui bahwa rata-rata laba pedagang per bulan selama 3 bulan terakhir yang paling rendah yaitu sebesar Rp. 966.666 dan laba yang paling tinggi yaitu sebesar Rp. 15.000.000.

Pada penelitian ini perkembangan usaha atau laba pedagang di Pasar Baru Kuningan diklasifikasikan ke dalam tiga kelas dengan rentang sebesar Rp. 4.677.777 yang diperoleh dari rata-rata perkembangan usaha yang dilihat dari laba yang tertinggi rata-rata perkembangan usaha yang dilihat dari laba yang terendah / banyaknya kelas interval atau dalam operasi matematikanya Rp. 15.000 .000 - 966.666/3.

Kemudian rata-rata perkembangan usaha yang dilihat dari laba pedagang tergolong rendah karena mayoritas pedagang memiliki rata-rata laba antara $\mathrm{Rp}$. 966.666 - 5.644.443, hal tersebut karena banyak pedagang di pasar yang baru memulai kembali usahanya atau terbatas modal yang sedikit.

Berdasarkan hasil penelitian, diketahui bahwa rata-rata modal kerja per bulan selama 3 bulan terakhir yang paling rendah yaitu sebesar Rp. 333.333 dan modal kerja yang paling tinggi yaitu sebesar $\mathrm{Rp}$ 6.333.333.

Pada penelitian ini modal kerja pedagang di Pasar Baru Kuningan diklasifikasikan ke dalam tiga kelas dengan rentang sebesar Rp. 2.000 .000 yang diperoleh dari hasil rata modal kerja tertinggi - rata-rata modal kerja terendah / banyaknya kelas interval atau dalam operasi matematikanya (6.333.333-333.333)/3.

Diketahui pula bahwa rata-rata modal kerja pedagang tergolong rendah karena mayoritas pedagang tergolong memiliki rata-rata modal kerja antara Rp. 333.333 Rp. 2.333.333, modal kerja di atas merupakan modal yang digunakan untuk keperluan berdagang.

Menurut hasil penelitian, ada enam ciri perilaku kewirausahaan, yaitu:

1. Keterampilan mengambil keputusan dan risiko yang moderat, serta bukan atas dasar kebetulan belaka.

2. Energik, khususnya dalam berbagai bentuk kegiatan inovatif.

3. Memiliki sikap tanggung jawab individual.

4. Mengetahui hasil-hasil dari berbagai keputusan yang diambilnya, dengan tolak ukur satuan uang sebagai indikator keberhasilan.

5. Mampu mengantisipasi berbagai kemungkinan di masa mendatang.

6. Memiliki kemampuan berorganisasi, meliputi kemampuan kepemimpinan dan manajerial.

Pada penelitian ini, perilaku kewirausahaan diukur berdasarkan ciri-ciri perilaku kewirausahaan yaitu energik, 
memiliki sikap tanggung jawab individual dan memiliki kemampuan berorganisasi.

Ciri yang pertama, energik, yang dimaksud dalam penelitian ini adalah bersemangat dalam menjalankan usahanya, bersemangat itu sendiri bisa dilihat bahwa orang tersebut selalu bersemangat pada saat membuka dan menutup usahanya apakah dia selalu lebih awal dibanding dengan pedagang lainnya atau tidak, kemudian dilihat dari kerapihannya, orang tersebut selalu merapihkan tempat berjualannya seperti membersihkan jongko, membersihkan timbangan, menyiapkan plastik, dan juga membersihkan dan merapihkan barang dagangannya sehingga dapat menarik konsumen. Pada kenyataannya di lapangan para pedagang di Pasar Baru Kuningan memiliki perilaku kewirausahaan energik ini bisa dilihat dari hasil penelitian bahwa mayoritas dari pedagang di Pasar Baru Kuningan selalu merapihkan tempat dan barang dagangan sebelum dan sesudah berdagang. Karena untuk menjaga kerapihan dan untuk menarik konsumen agar mau membeli di tempat mereka.

Ciri yang kedua, memiliki sikap tanggung jawab individual, yang dimaksud dalam penelitian ini adalah memiliki sikap tanggung jawab baik itu kepada usahanya sendiri atau kepada dirinya sendiri selaku pengelola usaha. Karena apabila orang tersebut tidak memiliki sikap tanggung jawab maka orang tersebut akan terkesan tidak peduli terhadap usahanya. Dalam penelitian ini memiliki sikap tanggung jawab dilihat dari teliti, menanggapi dengan baik keluhan konsumen, memberikan pelayanan yang baik, dan tegas. Teliti di sini adalah ketika membeli barang dari distributor atau dari tengkulak orang tersebut akan memeriksanya dengan teliti agar tidak ada kesalahan yang mengakibatkan kekecewaan pelanggan karena barang tidak sesuai dengan keinginan, oleh karena itu pedagang harus betul-betul teliti dalam membeli barang agar barang dagangannya bisa laku terjual sehingga dapat menghasilkan laba yang cukup tinggi.

Menanggapi dengan baik keluhan komsumen maksudnya adalah apabila ada konsumen yang mengeluh mengenai barang dagang yang sudah buruk kondisinya atau ada cacat dan meminta ganti rugi ataupun komplain, pedagang tersebut tidak merasa sakit hati atau marah karena dengan adanya saran dari konsumen seperti itu pedagang tersebut akan lebih teliti kembali pada saat membeli barang dari distributor atau tengkulak sehingga tidak akan merugikan dirinya sendiri dan membuat pelanggan atau konsumen puas dengan barang dagangannya. Memberikan pelayanan yang baik, dalam penelitian ini yang dimaksud dengan memberikan pelayanan yang baik adalah dengan cepat dan tanggap dalam melayani konsumen dan bersikap ramah terhadap konsumen.

Tegas, yang dimaksud dalam penelitian ini adalah pedagang tersebut tegas dalam mengingatkan pegawai atau orang yang membantunya pada saat berdagang, misalnya apabila pegawai tersebut melakukan kesalahan akan menegur secara langsung agar dia tidak mengulangi kesalahan yang sama lagi, hal itu dilakukan sebagai salah satu upaya memberikan pelayanan yang baik kepada pelanggan.

Ciri yang ketiga, memiliki kemampuan berorganisasi, yang dimaksud dalam penelitian ini adalah kemampuan dalam mengorganisir semua yang ada dalam usahanya baik itu dengan pegawai, sesama pedagang atau dengan distributor atau tengkulak dan juga dengan konsumennya. Dalam penelitian ini memiliki kemampuan berorganisasi dilihat dari disiplin dan memberikan apresiasi. Disiplin yang dimaksud adalah disiplin terhadap waktu, disiplin kepada diri sendiri maupun pegawai. Memberikan apresiasi di sini adalah seseorang yang mempunyai usaha memberikan bonus kepada pegawai atau 
orang yang membantunya selama berjualan apabila bekerja dengan baik dan tekun. Pada kenyataan di lapangan, mayoritas pedagang di Pasar Baru Kuningan memiliki sikap disiplin yang cukup baik yang ditandai dengan pedagang di sana selalu tepat waktu. Tetapi tidak semua pedagang di Pasar Baru Kuningan memberikan apresiasi kepada pegawainya, karena tidak semua pedagang mempunyai pegawai kalaupun pedagang itu memiliki pegawai biasanya pegawai tersebut hanya menerima bonus pada saat hari-hari besar saja.

Dari pernyataan di atas dapat disimpulkan bahwa dengan meningkatkan perilaku kewirausahaan maka $\mathrm{k}$ ebutuhan pasar akan terpenuhi dan dengan terpenuhinya kebutuhan pasar maka akan menambah pendapatan dan biaya untuk keperluan berdagang akan stabil, dengan bertambahnya pendapatan dan pengeluaran yang stabil maka laba yang didapat pun akan meningkat sehingga perkembangan usahanya bisa meningkat secara perlahan. Maka apabila para pedagang di Pasar Baru Kuningan ingin memperoleh laba yang besar maka para pedagang ini harus bisa mengembangkan perilaku kewirausahaan.

Tetapi dalam penelitian ini tidak semua ciri tersebut digunakan dalam penelitian karena disesuaikan dengan sektor informal di Pasar Baru Kuningan. Dengan demikian dalam penelitian ini hanya mengambil beberapa ciri perilaku kewirausahaan yaitu, energik; dalam hal ini dilihat dari seberapa bersemangatnya pedagang tersebut menjalankan usahanya, memiliki sikap tanggung jawab individual; dalam hal ini dilihat dari seberapa teliti dalam membeli barang dagangan, menanggapi dengan baik keluhan konsumen, memberikan pelayanan yang baik dan tegas, dan ciri yang terakhir yaitu memiliki kemampuan berorganisasi; dalam hal ini dilihat dari disiplin dan memberikan apresiasi kepada pegawai.

Dari analisis data penelitian dan uji hipotesis dapat diketahui bahwa modal kerja berpengaruh positif dan signifikan terhadap perkembangan usaha pelaku sektor informal di Pasar Baru Kuningan. Artinya, semakin besar modal kerja pedagang di Pasar Baru Kuningan maka akan meningkat pula perkembangan usahanya.

Modal kerja dilihat dari jumlah modal yang dimiliki, baik itu modal sendiri atau modal pinjaman. Modal sendiri, didapat dari hasil keseluruhan pendapatan yang kemudian dianggarkan untuk modal usaha pada bulan selanjutnya. Modal pinjaman, didapat dari pinjaman yang berasal dari bank, koperasi atau perseorangan. Berdasarkan penelitian di lapangan hampir seluruh pedagang mempunyai modal sendiri sementara sedikit diantaranya mempunyai modal berupa modal pinjaman. Dari data yang diperoleh, rata-rata modal kerja per bulan yang dimiliki oleh pelaku sektor informal di Pasar Baru Kuningan antara Rp. 333.333 - Rp. 2.333.333, modal kerja di atas merupakan modal yang digunakan untuk keperluan berdagang menunjukkan bahwa modal yang dimilikinya masih cukup rendah.

Dari analisis data penelitian dan uji hipotesis dapat diketahui bahwa perilaku kewirausahaan berpengaruh positif dan signifikan terhadap perkembangan usaha pelaku sektor informal di Pasar Baru Kuningan. Artinya, semakin tinggi perilaku kewirausahaan pedagang di Pasar Baru Kuningan maka akan meningkat pula perkembangan usahanya. Secara umum perilaku kewirausahaan berpengaruh positif dan signifikan terhadap perkembangan usaha. Artinya ketika perilaku kewirausahaan seorang pedagang itu tinggi maka perkembangan usahanya pun akan meningkat. Dari data dan hasil penelitian menunjukkan bahwa setiap perilaku kewirausahaan meningkat maka laba yang diperoleh para pedagang akan naik sebesar Rp. 36. Hal itu didapat dari persamaan hasil pengolahan data dengan responden pedagang di Pasar Baru Kuningan. 
Pada penelitian ini, keterampilan mengelola adminsitrasi dilihat dari apakah pelaku sektor informal atau pedagang tersebut rajin menulis atau mencatat seluruh pendapatan dan pengeluaran dalam sebuah buku atau catatan. Hasil dari penelitian ini menunjukkan bahwa keterampilan mengelola administrasi tidak memberikan kontribusi apapun terhadap laba atau perkembangan usaha.

\section{KESIMPULAN DAN SARAN}

\subsection{Kesimpulan}

Berdasarkan hasil penelitian dan pembahasan, maka penulis dapat menarik kesimpulan sebagai berikut:

1. Modal kerja yang dimiliki oleh para pelaku sektor informal di Pasar Baru Kuningan berada pada kategori rendah, perilaku kewirausahaan yang dimiliki oleh para pelaku sektor informal di Pasar Baru Kuningan berada pada kategori sedang, keterampilan mengelola administrasi yang dimiliki oleh para pelaku sektor informal di Pasar Baru Kuningan berada pada kategori sedang, dan laba atau perkembangan usaha yang dimiliki oleh para pelaku sektor informal di Pasar Baru Kuningan berada pada kategori rendah.

2. Modal kerja, perilaku kewirausahaan dan keterampilan mengelola administrasi secara bersama-sama berpengaruh secara simultan terhadap perkembangan usaha sektor informal di Pasar Baru Kuningan. Artinya jika modal kerja, perilaku kewirausahaan dan keterampilan mengelola administrasi meningkat secara bersamaan maka perkembangan usaha sektor informal di Pasar Baru Kuningan akan meningkat juga.

3. Modal kerja memiliki pengaruh positif dan signifikan terhadap perkembangan usaha sektor informal di Pasar Baru Kuningan. Artinya dengan adanya penambahan modal kerja maka akan bertambah pula perkembangan usaha sektor informal di Pasar Baru Kuningan.

4. Perilaku kewirausahaan memiliki pengaruh positif dan signifikan terhadap perkembangan usaha sektor informal di Pasar Baru Kuningan. Artinya dengan adanya peningkatan perilaku kewirausahaan maka akan meningkat pula perkembangan usaha sektor informal di Pasar Baru Kuningan.

5. Keterampilan mengelola administrasi tidak memiliki pengaruh terhadap perkembangan usaha sektor informal di Pasar Baru Kuningan.

\subsection{Saran}

Berdasarkan hasil penelitian yang telah diuraikan dan kesimpulan yang diperoleh maka ada beberapa saran yang penulis rekomendasikan adalah sebagai berikut :

1. Modal kerja merupakan faktor yang sangat penting dalam meningkatkan perkembangan usaha, oleh karena itu para pelaku sektor informal di Pasar Baru harus memiliki modal kerja yang cukup untuk menjalankan usaha atau bahkan untuk memperbesar usahanya.

2. Perilaku kewirausahaan yang dimiliki oleh para pelaku sektor informal di Pasar Baru Kuningan harus tetap dipertahankan bahkan harus ditingkatkan lagi agar dapat mempertahankan usaha yang sudah dimiliki saat ini dan dikembangkan lagi dengan mengikut kegiatan seminar ataupun pelatihan kewirausahaan yang diadakan Kementrian KUKM.

\section{DAFTAR PUSTAKA}

Alma, Buchari. 1997. Dasar-Dasar Bisnis dan Pemasaran. Bandung : Alfabeta 2006. Pengantar Bisnis Edisi Revisi. Bandung: Alfabeta 
Arikunto, Suharsimi. 2006. Prosedur Penelitian Suatu Pendekatan Praktik. Jakarta : Rineka Cipta

\section{Prosedur}

Penelitian Suatu Pendekatan Praktik. Jakarta : Rineka Cipta

Budiwati, Neti, dan Lizza Suzanti. 2010. Manajemen Keuangan Koperasi : Konsep dan Aplikasi. Kuningan : Laboratorium Koperasi Universitas Pendidikan Indonesia

Case, Karl E, dan Ray. C Fair. 2007. Prinsip-prinsip Ekonomi Edisi Kedelapan Jilid I. Jakarta: Erlangga.

Erdinal, Desita Eka. 2013. Analisis Faktorfaktor yang Mempengaruhi Produktivitas Tenaga Kerja (Industri Kecil Pengolahan Strawberry di Desa Alam Endah Kec. Rancabali Kab. Kuningan). Bandung : Skripsi UPI

Hendri Saparini dan M. Chatib Basri. 2009. Pengusaha Sektor Nonformal sebagai Penggerak Pembangunan Bangsa. Universitas Indonesia.

Hasbullah. 2008. Dasar-Dasar Ilmu Pendidikan Edisi Revisi. Jakarta : PT. Raja Grafindo Persada.

HIPKI. 1979. Pengembangan dan Perlindungan Pengusaha Kecil. Jakarta: Mutiara.

Ikhsan, Fuad. 2003. Dasar-dasar Kependidikan. Jakarta : Rineka Cipta

Kasmir, S.E., M.M. 2008. Kewirausahaan. Jakarta : PT Raja Grafindo Persada

Kuncoro, Mudrajad. 2003. Ekonomi Pembangunan Edisi Ketiga. Yogyakarta : Unit Penerbit dan Percetakan AMP YKPN

Lingga, Insanuddin. 2009. Analisis Faktorfaktor yang Mempengaruhi Pendapatan Pengusaha Industri Kecil di Kabupaten Dairi. Medan : Tesis Universitas Sumatera Utara (http://repository.usu.ac.id/bitstream/1 234.pdf) (Diunduh pada 21 September 2013)

Manning, Chris, dan Tadjuddin Noer Effendi. 1996.

Urbanisasi,
Pengangguran, dan Sektor Informal di Kota. Jakarta : Yayasan Obor Indonesia

Marolly, J. A. 1981. Bimbingan Praktis : Administrasi dan Usaha. Surabaya: Usaha Nasional

Oktawidara. 2012. Pengaruh Modal Kerja Terhadap Kinerja Perusahaan (Studi Kasus pada Rumah Sakit Umum Daerah Ciamis). Tasikmalaya : Skripsi Universitas Siliwangi (https://journal.unsil.ac.id/2Fdownload .php) (Diunduh pada 14 Oktober 2013)

Purwanti, Endang. 2012. Jurnal Among Makarti, Vol. 5 No.9, Juli 2012. (http://jurnal.stieama.ac.id/index.php/a ma/article/viewFile/65/46) (Diunduh pada 14 Oktober 2013)

Riduwan dan Akdon. 2010. Rumus dan Data dalam Analisis Statistika untuk Penelitian (Administrasi PendidikanBisnis-Pemerintah-Sosial-KebijakanEkonomi-Hukum-ManajemenKesehatan). Bandung: Alfabeta

Riduwan dan Sunarto. 2012. Pengantar Statistika untuk Penelitian Pendidikan, Sosial, Ekonomi, Komunikasi dan Bisnis. Bandung: Alfabeta

Rahmat, Pupu Saeful. 2008. Pengantar Ilmu Pendidikan. Prodi Pendidikan Ekonomi. FKIP. Universitas Kuningan.

2010. Metode Penelitian Pendidikan. Bandung: Alfabeta.

Suryana. 2006. Kewirausahaan. Bandung: Alfabeta.

Badan Pusat Statistik. 2016. Kuningan Dalam Angka Tahun 2016. Kuningan: Badan Pusat Statistik Kota Kuningan.

Data Perkembangan Koperasi, UKM dan Industri Perdagangan Kabupaten Kuningan

(http://www.Kuningan.go.id/images/downl oad/perkembangankukmdanindustri.pd f) (Diunduh pada 13 Juli $2017:$ 11.53) (http://Kuningan.bps.go.id/subyek/perdagan gan-Kabupaten-Kuningan) (Diunduh pada 08 Juli 2017 : 13:52). 